\title{
Quantifying the Costs and Benefits of Coastal Water Quality Improvements in the Ko Chang Marine National Park, Thailand
}

\author{
Sunida Piriyapada $\cdot$ Erda Wang
}

Received: 9 November 2013 / Accepted: 21 December 2013 /Published online: 24 April 2014

(C) Springer International Publishing Switzerland 2014

\begin{abstract}
The water quality in Ko Chang Marine National Park coast has been problematic for many years. Recently, a conservation plan has been made by the local government for protecting the ocean beaches by constructing a sewage treatment plant in the region. This study uses the contingent valuation method $(\mathrm{CVM})$ to measure the benefits associated with the proposal of the wastewater treatment plant (WWTP), followed by conducting cost-benefit analysis (CBA) in order to justify the feasibility of the public fund appropriation by the government fiscal policy, such as taxes. A completed questionnaire survey of 300 randomly clustered households was analyzed. Household willingness to pay (WTP) was estimated using Tobit models. The results indicate that the mean WTP for the proposed wastewater treatment project is $\$ 73.36$ per household per year, translating into an aggregate monetary benefit of $\$ 298,774$ per year for the local community. Additionally, the CBA result shows that the net present value (NPV) of the project attains $\$ 465,162.48$ per year, internal rate of return (IRR) reaches $9.14 \%$, and benefit-cost ratio $(\mathrm{B} / \mathrm{C})$ ends up with 2.21 with all those intangible benefits excluded from the calculation. Therefore, the proposed wastewater treatment plant project is economically profitable.
\end{abstract}

Keywords Willingness to pay - Contingent valuation - Cost-benefit analysis - Tobit model . Wastewater treatment plant

\section{Introduction}

Thailand possesses a total coastline of about 2,600 km. Due to its unique geographical characteristics, the coastline represents an important attraction and contributes significantly to the overall tourism revenue for the nation. Specifically, the Ko Chang Marine National Park (KCMNP) represents a typical beach park in Thailand where there are abundant tourism

\footnotetext{
S. Piriyapada $(\bowtie) \cdot$ E. Wang

Department of Human Resource and Tourism Management, School of Business Management, Dalian University of Technology, No. 2 Linggong Road, Dalian 116024, China e-mail: sunidaar@hotmail.com

E. Wang

e-mail: edwang@dlut.edu.cn
} 
resources, including high quality beaches, corals, offshore islands and natural scenery; all these ultimately become major resources for mass tourism development.

Nevertheless, the long stretches of Ko Chang coastline are threatened by bacterial contamination from the surrounding island community, mainly due to its rapid economic development, accompanied by a great number of migrants who settled down in the vicinity of the coastal area. The high density of population in tourism areas and the inadequate infrastructure pose a serious threat to the coastal park environment, and the coastal ecological system as well. One threat comes from wastewater discharge, directly resulting from household uses. Historically, this problem of sewerage discharge was not considered as a big issue, owing to its relatively small magnitude, but, in recent years, as a result of the rise of the population and the number of tourists, ocean water pollution has turned out to be a serious hazard noticed by the local government and tourists. Policy makers have expressed significant interest in policy relevant non-market valuation and the use of market-based instruments to ensure efficient use and conservation (Molinos et al. 2010).

While the environmental resource valuation could link human welfare and natural systems to ensure ecologically sustainable development (Howarth and Farber 2002; Chen and Jim 2008), one of the key pieces of information in the process is to obtain the economic value accrued to each type of natural resource and its related recreational activity. As this information is acquired, a maximum economic efficiency could be achieved by using the principle of marginal cost being equal to marginal benefits (Ahmed and Gotoh 2006). One commonly used method to disclose a non-market resource value is the contingent valuation approach, according to which individuals are asked to state their willingness to pay (WTP) for non-market benefits, or their willingness to accept (WTA) compensation for non-market costs (Mitchell and Carson 1989). Another economic analysis, which compares the monetary costs and the benefits of a public project, is the cost-benefit analysis, which provides the economic feasibility associated with the implantation of a proposed policy action (Prest and Turvey 1965; Price 2000). In determining whether a public investment is socially profitable, a decision criteria of CBA is typically performed using three financial indicators: the net present Value (NPV), the internal rate of return (IRR) and the benefit-cost ratio (B/C).

In order to achieve environmentally sound management, a survey of local residents in the Ko Chang was administrated, which involves local residents' public preferences and willingness to pay for nature conservation, as a means to assess public acceptances into the economic value that they attach to a public good or service (Pavlikakis and Tsihrintzis 2003). In this paper, using the concept of the joint CVM and CBA analysis, a quantification of the environmental benefits derived from the coastal water depollution program is made to support economic decisions. The novelty of this study aims to assess a community's preference for the proposed wastewater treatment project (WWTP) in the KCMNP with three objectives: (i) to evaluate the non-market value accorded by household willingness to pay for coastal water quality improvements through the WWTP; (ii) to obtain the economic feasibility of the operation and maintenance of the WWTP; (iii) to suggest new research directions in order to justify public investments related to non-market resources in the other marine parks.

The paper is organized in six sections. Section 2 gives a brief review of literature associated with economic valuation methods used in quantifying the environmental benefits of the WWTP. Section 3 presents the background of the studied location, and then Section 4 discusses the research methodology and data collection for the analysis. Section 5 explores the public's willingness to pay in relation to the feasibility study of the municipal treatment plant, followed by a final section of the conclusion. 


\section{Literature Review}

In this environmental valuation study, we use the contingent valuation which is a stated preference method to derive empirically robust estimates of the household WTP for water depollution in the coastal areas. More specifically, the value of the WWTP reflects the households' WTP to reduce the frequency and severity of future discharge of wastewater into ocean water.

The validity of contingent valuation has been a much debated issue in the economic literature (Bengochea et al. 2005; Hausman 2012), that is because CVM relies on hypothetical WTP which could not be founded upon actual behaviors. Therefore, hypothetical CVM data can result in economic values that are biased upwards, affecting the validity and credibility of stated preference estimates (Ajzen et al. 2004; Collins and Vossler 2009; Poe and Vossler 2011). To date, economists make efforts to eliminate hypothetical bias in eliciting accurate economic values through a well-designed questionnaire (Pavlikakis and Tsihrintzis 2006), that such bias and inconsistency has been successfully minimized. As a result, despite the limitations of the CVM, today a considerable body of evidence supports the view that contingent valuation done appropriately can provide valid and reliable responses for valuing well-defined public goods (Carson 2012).

Since we are proposing the contingent valuation questions to improve the quality of coastal water resources to be delivered to island communities, the maintenance of water bodies in the coastal area requires public funds that could be compared with the aggregate WWTP valuation. The CBA provides a systematic process to justify the economic feasibility by bringing elements of transparency and objective water resource management (Prihandrijanti et al. 2008). By using the CBA approach, a lot of the controversy surrounding environmental valuation has been the subject of debate, due to the overly restrictive valuations (Brouwer 2000). The valuation method underlying CBA is considered too narrow and simple to properly measure the environmental values that people depend on natural resources. To minimize the controversial issues in the model, economists attempt to combine a WTP approach with a CBA as the estimations of the social preferences (Báez and Herrero 2012; Verlicchi et al. 2012).

Many previous publications have addressed the non-market benefits of improvements in water resource quality. In most applications, environmental externalities related to discharge of wastewater have been quantified using the CVM (Bergstrom et al. 2000; Bateman et al. 2006; Birol et al. 2006; Del Saz et al. 2009; Molinos et al. 2010). There are a few studies that employed a valuation scenario that frames marine water falling into passive uses. For example, Bockstael et al. (1989) addressed the CVM questions to measure the human values from the Chesapeake Bay. A questionnaire was designed to elicit individuals' attitudes and their maximum willingness to pay for the changes in water quality. They also studied the benefits associated with a reduction in nutrients in coastal waters. According to their study results, the value for a moderate water quality improvement in term of the aggregate WTP ranged from $\$ 10$ to $\$ 100$ million in 1984 dollars. However, there are different methodologies for the economic valuation of environmental externalities related to wastewater issues. This is consistent with results obtained by a study of Godfrey et al. (2009). They applied a CBA to estimate a greywater reuse system in India. Hedonic prices and CVM were conducted to determine monetary values of external benefits and costs pertaining to environmental and health benefits. Likewise, Seguí et al. (2009) investigated the environmental benefits arising from wastewater reuse in the context of a wetland restoration project in the Natural Wildlife Park of Aiguamolls de l'Emporda, northeastern Spain. Based on the travel cost method, they found that the price of the reclaimed water in the park ranged between $0.75 / \mathrm{m}^{3}$ (without opportunity cost) and $1.20 / \mathrm{m}^{3}$ (with opportunity cost). In addition, Verlicchi et al. (2012) 
carried out a technical and economic feasibility study for a reuse project of reclaimed water in the Po Valley of northern Italy. The CVM application was used to assess public acceptance for estimating WTP values of a perceived benefit. The results indicated that each family was willing to contribute financially in a one-off payment of $€ 54$, resulting in aggregate benefits of $€ 3,484,728$. Furthermore, the CBA indicators were calculated and compared the costs and benefits associated with the project, yielding the following results: the NPV amounted to $€ 40,001$, the IRR was exactly $5 \%$ and the $\mathrm{B} / \mathrm{C}$ ratio equaled 1.007 . These financial indicators evidenced that the project was economically acceptable.

\section{Study Location}

The KCMNP has historically been an important attraction for both domestic and oversea visitors. It is geographically situated at $11^{\circ} 56^{\prime}-12^{\circ} 16^{\prime} \mathrm{N}$ and $102^{\circ} 25^{\prime}-102^{\circ} 61^{\prime} \mathrm{E}$ in the Trat Province of eastern Thailand, covering an area of $650 \mathrm{~km}^{2}$ of which $458 \mathrm{~km}^{2}$ consists of surface water. Ko Chang's coast comprises a long shoreline with white sand beaches. As such, the beaches cover numerous coves and clear coastal water support a plentiful nautical life (Mu Ko Chang National Park 2013) (Fig. 1). According to the 2011 census, the KCMNP has a population of 107,033

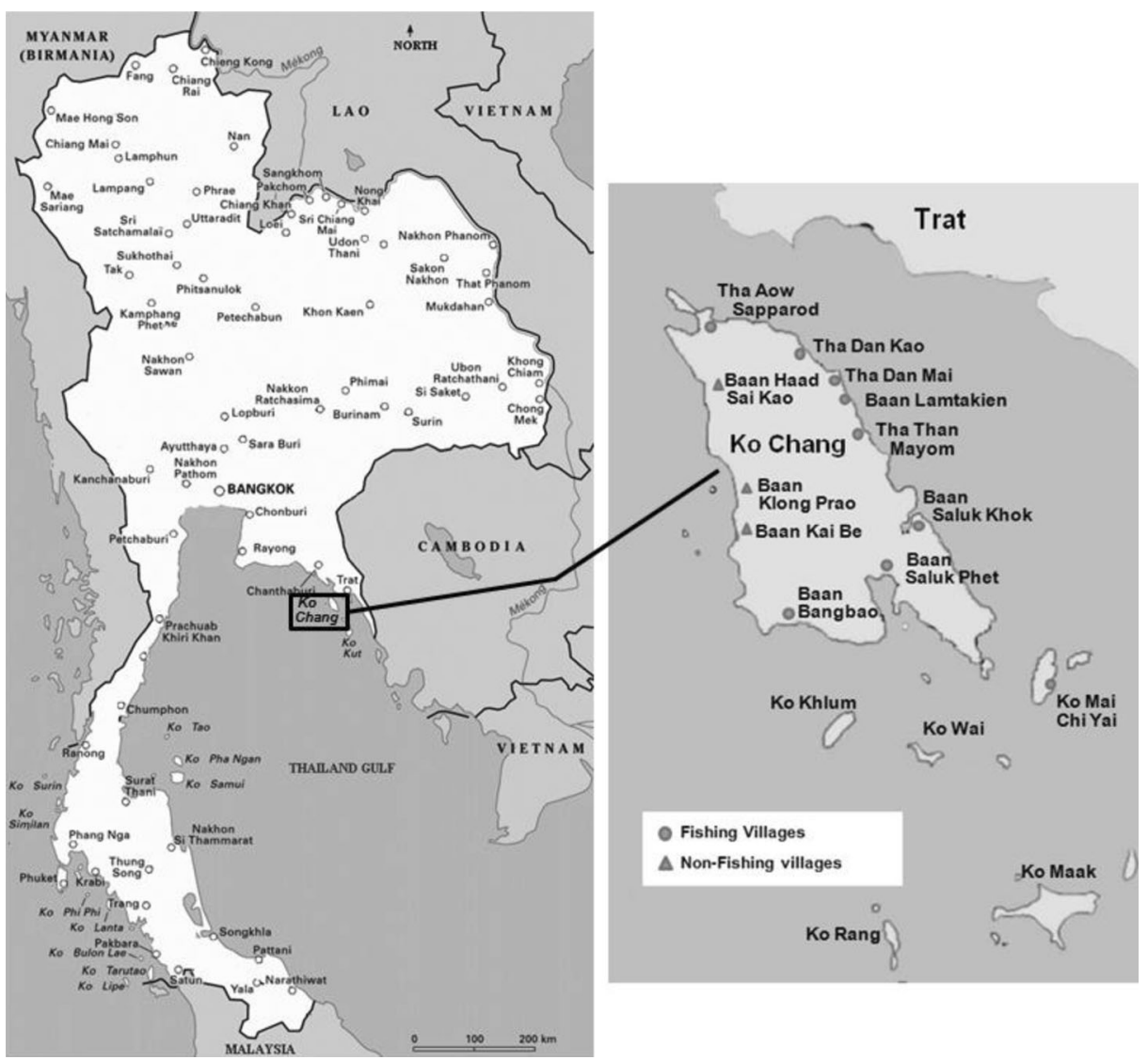

Fig. 1 Map of the KCNMP (Source: Tourism Authority of Thailand 2013) 
people, who live in nine villages; the population density of this island is 33.53 people $/ \mathrm{km}^{2}$ (Thailand National Statistical Office 2013). Ko Chang was designated as a Marine National Park in 1982 by the Thailand government. It was assigned to be an area having special or unique tourism features, and was identified as a new tourism destination in 2002. Furthermore, the government has established the Development Area for Sustainable Tourism Authority (DASTA) to carry out tourism projects at the KCMNP. The integrated management framework will be applied in the Ko Chang, which is in the scope of encouraging tourism promotion along with improving local infrastructure and conserving natural resources.

Tourism in Ko Chang showed rapid growth over the last decade (Fig. 2). In 2012, the coastal tourism development brought about 900,000 visitors and generated some \$255 million (Thailand Department of Tourism, 2013). However, tourism development in tropical coastal areas frequently results in significant environmental degradation over the years, as a result of a rapid increase in tourism demand and inadequate input to the park management. Most beaches in the KCMNP have been facing a series of threats coming from over-capacity uses and multiple sources of pollution, including but not limited to human wastes, sewerage, drainage, coastal erosion, and encroachment (Department of Mineral Resources 2013), especially to the ocean reefs. The quality of coral reefs in the KCMNP has been deteriorated at an unprecedented rate (United Nations Environment Programme 2007).

The KCMNP covers the most popular beach area, which was selected for the study, namely, Haad Sai Khao (White Sand Beach). At present, it can be accessed by visitors free of charge. This beach park itself turns out to be a main tourist destination as far as the number of tourist arrivals and overnight stays are concerned. In recent years, an insufficient budgeting has jeopardized water pollution control policies in the coastal zone. Moreover, law enforcement that would restrict pollution from household consumption and tourism operations is weakly regulated due to lack of capacity. As a tourism development result, the large increase in the number of tourists during the summer months (November-April) results usually in an increase in the amount of wastewater produced. There are currently no wastewater collection and treatment facilities in this area, except for on-site systems. Sewage and wastewater directly overflow from household and community discharges into the ocean via underground piping

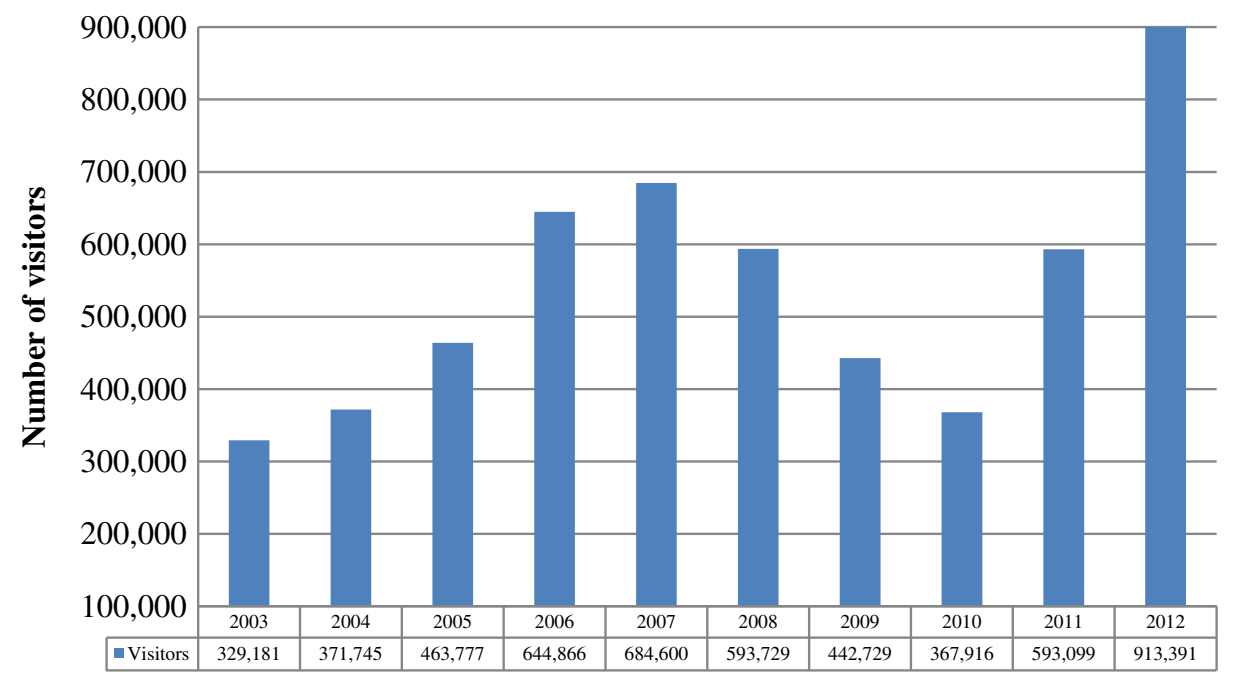

Fig. 2 Number of visitors to the KCMNP (Source: Thailand Department of Tourism 2013) 
along the coastline. If the necessary wastewater facilities for handling these wastes are not constructed, the ocean water will be polluted, causing serious hazard problems (Günay 1989).

\section{Methodology}

\subsection{Tobit Model}

The Tobit model is most often applied to value censored regression models and is usually estimated by the maximum likelihood estimation (Greene 2000). In this study, a discrete choice followed by open-ended question was used to elicit the declared WTP of respondents including zero. The Tobit command was used to analyze the characteristics of households that state the probability of WTP and the maximum WTP of the respondents for the proposed WWTP (Cho et al. 2005). Following Greene (2000) and Wooldridge (2002), the Tobit model can be expressed as:

$$
\begin{gathered}
W T P_{i}=X_{i} \beta+\varepsilon_{i} \quad X_{i} \beta+\varepsilon_{i}>0 \\
W T P_{i}=0 \quad X_{i} \beta+\varepsilon_{i} \leq 0
\end{gathered}
$$

where WTP indicates a vector of willingness to pay which is censored at zero; $X_{i}, \varepsilon_{i}$ and $\beta$ denote a vector of explanatory variables, a random disturbance term, and a parameter vector common to all households, respectively. Assuming that $\varepsilon_{i}$ is independent and normally distributed with mean zero and common variance sigma square (Yoo et al. 2001), the expected WTP values E(WTP) for an observation can be written as:

$$
E(W T P)=\Phi\left(\frac{X \beta}{\sigma}\right) X \beta+\sigma \varphi\left(-\frac{X \beta}{\sigma}\right)
$$

where $X$ is a matrix of socioeconomic variables that are simply hypothesized to influence WTP; $\beta$ reflects the vector of unknown parameters to be investigated with respect to the matrices of explanatory variables $X$ (Amemiya 1973); $\Phi, \varphi$ and $\sigma$ indicate the normal distribution function, the normal density function, and the standard deviation, respectively. Then, the maximum WTP can be expressed as:

$$
E(W T P)=\varphi(X \beta / \sigma) E(W T P *)
$$

where $E\left(W T P^{*}\right)$ is a value of the expected WTP for above zero (it should be noted that a value of the expected WTP is observed when it is greater than zero). Given that the Tobit estimation is a censored linear model, the marginal effects of changes in the explanatory variables are nonlinear, and thus, not equal to $\beta_{i}$ (Johnston and Dindaro 1997). According to McDonald and Moffitt (1980), the marginal effects of a change in the explanatory variables $\left(i^{\text {th }}\right)$ of $X$ on the probability of WTP is:

$$
\partial E(W T P) / \partial X_{i}=\Phi(X \beta / \sigma)\left(\partial E(W T P *) / \partial X_{i}\right)+E(W T P *)\left(\partial \Phi(X \beta / \sigma) / \partial X_{i}\right)
$$

\subsection{Cost Benefit Analysis}

All assessed public services in the marine park require large investment costs. The public funds need to compare the financial-economic feasibility of public infrastructure projects, such as the WWTP with varying investment outlays and maintenance costs (Penning et al. 2005). By using a CBA approach, we were thus able to calculate a monetary value of the WWTP in 
different scenarios in order to justify the feasibility of the public fund whether the project is financially feasible. We also applied the net present value (NPV) and internal rate of return (IRR) for each feasible scheme to be weighed up, and compared the benefits $\left(\mathrm{B}_{\mathrm{t}}\right)$ and costs $\left(\mathrm{C}_{\mathrm{t}}\right)$ based on the establishment of the WWTP project and that occurring in each period $t$ over the expected lifespan of the project $T$ (Roebeling et al. 2011).

According to Zerbe and Dively (1994), once the cost-benefit analysis was performed to assess the economic feasibility, the formulas for calculating the NPV, IRR and B/C ratio are given by:

$$
\text { Net Present Value }(N P V)=\sum_{t=0}^{T} \frac{B_{t}-C_{t}}{(1+i)^{t}}
$$

$$
\text { Internal rate of return }(\mathrm{IRR})=\sum_{t=0}^{T} \frac{B_{t}}{(1+r)^{t}}=\sum_{t=0}^{T} \frac{C_{t}}{(1+r)^{t}}
$$

$$
\text { Benefit-cost ratio(B/C ratio })=\frac{\sum_{t=0}^{T} \frac{B_{t}}{(1+i)^{t}}}{\sum_{t=0}^{T} \frac{C_{t}}{(1+i)^{t}}}
$$

where $r$ is the time discount rate. The NPV of a project is defined as the discounted sum of differences between benefits and costs; the NVP-rule states that the project is economically profitable in case NPV is greater than zero (NPV $>0$ ). The IRR is defined as the discount rate that equates the present value of the benefits and the costs of the project over the lifetime (note that the NPV $=0$ at the IRR). The viability of the project is demonstrated, if an IRR value is greater than $r$. A project with a benefit to cost ratio is economically justified when the $\mathrm{B} / \mathrm{C}$ ratio is greater than one. Generally, the higher the $\mathrm{B} / \mathrm{C}$ ratio is, the more efficient is the use of available resources (Stewart and Possingham 2005).

\subsection{Data Collection}

Data were obtained from 324 surveys administered on-site to households at the Ko Chang during April to May 2013. A clustered sampling procedure was adopted. Nine residential sites were selected randomly along the shorelines at the KCMNP. At each site, 35-40 households were randomly selected for the survey via household address notation. In order to obtain a representative sample, a household head or a family member (aged 20 or above), who was the decision-making person, was invited for a face to face interview in their homes (Chen and Jim 2008). This method is strongly recommended by Mitchell and Carson (1995), because it could ensure the accuracy of value estimates (Forster 1989). The declared WTP of the respondent was, therefore, explained as pertaining to their entire households (Verlicchi et al. 2012). Four interviewers trained by interview specialists were involved, three of them college degree holders, and one researcher participated in the full CV survey. For this purpose, a two-day training was held to ensure that the interviewers could operate live interviews and fill in the survey form correctly.

Before the interview, the respondents were clearly explained the survey's purposes, content and each specific question. In case that the respondents misunderstood some questions, the interviewees provided clarification at the scene. Interviewers were instructed to interview only 
one person at a time in order to ensure the full completion of the survey form. The surveys were administered at least once for each day of the week and at least once for each of three time periods each day (9:00 to 11:00 a.m., 11:30 a.m. to 2:00 p.m., 4:00 to 6:30 p.m.). Each questionnaire took about $30 \mathrm{~min}$. Once the respondents agreed to be interviewed, a small token of appreciation was presented.

\subsection{Survey Instrument}

In this context, a questionnaire was designed following a focus group discussion, park manager's comments and previous studies in the CVM field (Bateman et al. 1993; Nunes Paulo 2002; Huhtala 2004), which consisted of three main parts. The first section dealt with household perception of the present status of beach and coastal waters, attitude towards coastal water quality and reliability, household sewage system and sanitation practices, opinions about public services and sanitation facilities.

The second section consisted of the contingent valuation questions. Before implementing the survey, a pre-test CV question was carried out in February 2013 in order to make modification to the designed questionnaire, to detect sources of bias and to verify the appropriate bidding values based on the data obtained from an open-ended question. Thirty households from two villages (Klong Son and Klong Prao) were recruited in the pilot test, each of the respondents was given the details on the purpose of sewage treatment construction on the island, the available facilities and the format used in contingent valuation techniques. A dichotomous choice format (close-ended) with an open-ended follow up question was used to elicit the WTP amount by asking respondents to state the maximum amount they would be willing to pay wastewater tariffs for improved beach water quality. Based on the pre-test, the question sequence was restructured, the wording of the questionnaire was refined to properly improve clarity between the respondents and the interviewers, the payment vehicle was chosen to be monthly tariffs, this is due to the fact that local population in the KCMNP are familiar with tax levies; and the starting bid value was also achieved. Mitchell and Carson (1989) suggested that questions related to socioeconomic characteristics should be placed at the end of the questionnaire. In the final part, demographic information about the households including gender, age, education level, family size, occupation, household monthly income as well as types of residences were collected.

In practice, respondents were presented a CVM hypothetical scenario and a dichotomous choice with open-ended follow up questions. Green et al. (1998) suggested that a dichotomous yes or no and open-ended elicitation question is useful to provide further explanation and offer individuals' real WTP than an alternative double referendum elicitation. Additionally, it is particularly helpful in overcoming the problems of high non-response rate and the unfamiliarity from hypothetical survey.

The hypothetical market scenario was designed to show the before project (current coastal water condition and sewage/wastewater) and after the project situations (improved coastal water quality and proposed wastewater solution); the hypothetical scenario was used to familiarize the households. The full CV survey questionnaire is presented in the Appendix.

\subsection{Costs of the Wastewater Treatment Plant for the KCMNP}

In the master plan for the year of 2014-2015, a pilot wastewater treatment plant has been approved to construct along with the $8 \mathrm{~km}$ long shoreline fronting White Sand Beach. The centralized treatment process (off-site management) typically includes: (i) a centralized collection system that collects sewage from residences and commercial uses through sewer lines; 
(ii) the transport of sewage to a municipal treatment plant at an off-site location; and (iii) the reuse or disposal of the treated effluent (Crites and Tchobanoglous 1998; Wilderer and Schreff 2000; Tokich and Kliot 2008). After the completion of the WWTP, ocean water samples from wastewater effluent disposal into the sea will be monthly collected for testing bacterial contamination, with the aim to meet in all water bodies water quality standards for fishing and swimming under the National Environmental Quality Act (NEQA) B.E. 2535 (1992). The centralized sewerage system will provide improved sewerage services to 1.5 million visitors and 25,000 inhabitants over the next 20 years, and treat up to 1.3 million $\mathrm{m}^{3}$ per year.

The quantification of the costs involved in the construction of the WWTP is straightforward because these costs are strictly directed by the operating companies. Table 1 lists the total estimated costs of the WWTP from year 2014 to 2035. The total costs can be divided into the following elements: (i) equipment costs typically include land acquisition, the construction cost of the treatment unit and some ancillary technologies in relation to wastewater treatment; (ii) project costs and civil work consist of installation, piping, instrumentation and controls, pumps, engineering studies, mechanical-chemical treatment and annual operation and management costs (O\&M costs); and (iii) total indirect costs comprise engineering, delivery, and contingency. The construction of the plant received \$2.7 million from the Regional Development and Social Protection Grant, financed by the DASTA (personal interview with Mr. Thatchai Wachararak, the Chief of Administration DASTA, on April 30, 2013).

\subsection{Data Description}

Descriptive statistics for those variables in the regression analysis are shown in Table 2. In a total of 324 interviews, 24 of respondents were unwilling to disclose demographic information, therefore, the full completion of 300 survey forms was analyzed. In summary, about $56 \%$ of the respondents are female and the remaining $44 \%$ are male. The dominant age group of respondents was about $31-40$ years old (32\%), followed by more than 50 years old ( $24 \%)$ and 21-30 years old $(21 \%)$. The majority of respondents had either a primary or a secondary

Table 1 Total costs of the wastewater treatment plant from year 2014 to 2035

\begin{tabular}{ll}
\hline Construction cost & Capital cost \\
\hline Total construction cost & $\$ 1,254,131.17$ \\
Equipment cost (Technology-Specific cost) & $\$ 322,145.04$ \\
Installation & $\$ 90,257.15$ \\
Coastal engineering studies and design & $\$ 389,576.63$ \\
Piping & $\$ 63,081.06$ \\
Mechanical-chemical treatment & $\$ 228,685.27$ \\
Operation and management costs (O\&M costs) & $\$ 352,181.45$ \\
Total indirect cost & $\$ 2,700,057.77$ \\
Engineering and contingency & \\
The estimated total cost (Construction cost + Total indirect Cost) &
\end{tabular}

The authors' calculation

1. Data are provided from the Designated Areas for Sustainable Tourism Administration (DASTA)

2. The commitment amount of the pipeline in the WWTP construction is indicative and may be altered during the project preparation

3. In monetary calculation, an exchange rate of $\$ 1.00$ equals 31.90 Thai Baht based on Bank of Thailand at the time of the survey in April-May 2013 
education (27\%), and high school education or vocational diploma (22\%) as their highest level of educational attainment. The household monthly income of a respondent in the KCMNP is relatively high with the average of being $\$ 4,740$, about six fold of monthly income earned by a Thailand household (Thailand National Statistical Office 2013). Most respondents earn $\$ 1000-\$ 5000$ in household income (48\%) per month, followed by $\$ 5001-\$ 10000$ per month (36\%) and less than $\$ 1000$ per month (8\%). The mean household size was reported to have three members. Most respondents are employed in private sectors $(31 \%)$, followed by government officials (14\%) and self-employed (12\%).

In the CVM questions, respondents were asked about their perception of the existing coastal water quality. About $100 \%$ of the local people were aware that there are water pollution and health hazards at the beach, and that sewage discharges were considered as a big issue. With regard to the current wastewater service, respondents were also asked to scale a variable from 1 to 5 about their satisfaction level of the sewage disposal operation. On the average, respondents were less satisfied with the wastewater management, which is evidenced by the very low score of 1.73 . Moreover, a total of 24 respondents $(8 \%)$ reported experiencing symptoms, such as vomiting, fever, itchy skin and eye irritation, arising after swimming in the sewage-polluted seawater.

\section{Empirical Results}

\subsection{Tobit Regression Results}

The estimation results of Tobit model are presented in Table 3. The results reveal that the eight explanatory variables influence the maximum WTP amount decision. All were found to be significant explanatory factors explaining the household willingness to pay for the proposed WWTP (Table 3). The dependent variable is a continuous variable that the households respond as the probability WTP and the maximum WTP for the wastewater treatment services concerning the benefits expected out of it (Wendimu and Bekele 2011).

The coefficient on the gender variable is positive and significant $(p<0.01)$ which means that females are more likely to pay for the WWTP service than males. This is consistent

Table 2 Descriptive statistics

\begin{tabular}{|c|c|c|c|c|}
\hline Variables & Label & Minimum & Maximum & Mean \\
\hline WTP & Willingness to pay for the WWTP & & & \\
\hline GEN & Gender 1 , if the respondent is female, 0 otherwise & 0 & 1 & 0.563 \\
\hline AGE & Age in year & 20 & 76 & 41.31 \\
\hline STA & Marital status 1 , if the respondent is married and 0 otherwise & 0 & 1 & 0.484 \\
\hline EDU & $\begin{array}{l}\text { Level of education } 1 \text {, if the respondent has a lower college degree, } 0 \\
\text { otherwise }\end{array}$ & 0 & 1 & 0.523 \\
\hline AVGHH & Household monthly income before tax in US dollars & 500 & 20,000 & 4,740 \\
\hline HHS & Household size & 1 & 6 & 2.822 \\
\hline EMP & $\begin{array}{l}\text { Employment status, } 1 \text { if the respondent has an employment, } 0 \\
\text { otherwise }\end{array}$ & 0 & 1 & 0.564 \\
\hline WATERQ & $\begin{array}{l}\text { Perception about quality of existing beach and coastal water, } 1 \text { if the } \\
\text { respondent recognized the poor ocean water quality, } 0 \text { otherwise }\end{array}$ & 0 & 1 & 0.982 \\
\hline BID & BID value & 0 & 20 & 6.42 \\
\hline
\end{tabular}


with the previous CVM studies indicating that females are more attentive to the environmental consciousness than men (Stern et al. 1993; Berrens et al. 1997; Bord and O'Connor 1997; Brown and Taylor 2000), other factors being constant. In contrast, the age variable has the expected negative parameter estimate, suggesting that older people have a lower probability of accepting the bid price increases and are willing to pay less than the younger generation. The marginal effect value with respect to age shows that the probability of the willingness to pay for the WWTP may decrease by $\$ 0.06$ when the age of a respondent increases by one year, ceteris paribus. Identically, the negative coefficients of the status revealed that particular samples of people who are single or widow are relatively more accepted to pay the bid offered than married people due to less demand for food and other necessities in such a status, given other factors held constant. This study also shows a significant negative influence of the education level on the WTP for the WWTP, indicating that the respondents with a college degree tend to be willing to pay more than lower educated ones. This is perhaps because those well-educated households are expected to be more aware about the pollution level of coastal water resources (Hanley et al. 2009), ceteris paribus.

In contrast, the household income variable shows a significant positive influence $(p<0.10)$ on paying an amount, indicating that richer households would notably raise WTP. The result was consistent with expectations of economic theory (Carson et al. 2001), indicating that an increase in income would lift the expectation of environmental quality resources. Hence, the WWTP program is normal goods. The marginal effect value of 0.0004 with respect to the household income variable shows that the probability WTP of wastewater tariffs for quality water improvement increases by $0.04 \%$ when the income of a household increases by $\$ 1$, other variables held constant. The coefficient on the household size variable is significantly correlated with the WTP dependent variable $(p<0.01)$; this suggests that the willingness to pay for the WWTP increases as household size increases. One possible explanation could be that those households who perceive the poor ocean water quality and health risks associated with the wastewater conditions are likely to pay more for improved sewerage services, ceteris paribus. Likewise, the employment variable is another variable found to be significant $(p<0.10)$, meaning that the employed respondents are more likely to say "yes" to payment.

Table 3 Maximum log likelihood estimates of Tobit model

\begin{tabular}{llll}
\hline Variables & Coefficient & Standard error & Marginal effect \\
\hline Constant & 1.635 & 1.796 & - \\
GEN & $2.205^{*}$ & 0.397 & $2.246^{*}$ \\
AGE & $-0.073^{*}$ & 0.023 & $-0.060^{*}$ \\
STA & $-1.309^{*}$ & 0.380 & $-1.285^{*}$ \\
EDU & $-1.064^{*}$ & 0.397 & $-0.958^{* *}$ \\
AVGHH & $0.0004^{*}$ & 0.00007 & $0.0004^{*}$ \\
HH & $0.512 *$ & 0.134 & $0.546^{*}$ \\
EMP & $1.160^{*}$ & 0.449 & $1.281^{*}$ \\
WATERQ & $3.704 *$ & 1.318 & $4.478^{*}$ \\
Number of observations & 300 & & \\
Sigma & 3.487 & & \\
Log likelihood & -1067.162 & & \\
\hline
\end{tabular}

*Indicates statistical significance at the $1 \%$ level; **indicates statistical significance at the $5 \%$ level 
Environmental factors, such as the ocean water quality, has a positive and significant $(p<0.01)$ effect on WTP, implying that the respondents who perceived ocean water pollution are more likely to pay for the treatment facilities, as the beach quality gets worse. The positive marginal value of the ocean water quality variable suggests that those people who recognized the poor quality of water bodies have a $4.48 \%$ more probability of paying monthly tariffs for the proposed WWTP compared to people who did not perceive the water pollution, keeping all other variables constant.

In the survey response rate, $89 \%$ of the households would support the WWTP program for the amount of wastewater tariffs. The 'zero' WTP was chosen by 33 (11 \%) households, denoting that the respondents were unwilling to accept towards the proposed WWTP program. Following standard practice in the CVM analyses, the households were asked to screen the protest zero bidder (Cho et al. 2005); this was to make sure that their refusal to value the WTP question was not caused by protest beliefs. We explored the insights of the protestors to enquire about the reasons for the rejection: (i) thirteen of the households stated that the they could not afford to pay more taxes; (ii) nine conceded that the government should pay for the sewage treatment plant; (iii) six needed more information before they decide to pay; and (iv) five were satisfied with the current beach and coastal water condition or opined that the WWTP project will not lead to the outcomes as claimed. The households who answered (ii) were classified as the protest responses who objected to an aspect of the CV survey or the willingness to pay.

Following Chen and Jim (2008), the estimated mean household WTP was computed by Eq. (2) to be $\$ 6.03$ per household per month (protest responses were included). According to the 2011 census, there were 4,639 households in the study area (National Statistical Office 2013). Assuming that $89 \%$ of the households would afford the coastal water preservation project, the total monetary benefits served by the proposed WWTP is worth $\$ 298,774.40$ per year.

\subsection{The WWTP Project Evaluation}

The viewpoints of this financial CBA were included: (i) economical (treatment unit, O\&M costs); (ii) the tangible costs as well as benefits from the WWTP were not included in the calculations; (iii) benefit start delayed by two years after finishing the WWTP intervention. In this section, CBA is calculated by comparing the total benefits derived from household WTP for improved water quality with the total costs for the WWTP construction. The three economic indicators revealed that the proposed WWTP is financially feasible, since the project benefits outweigh costs in all CBA outcomes. At a $7 \%$ discount rate (Bank of Thailand, as of May 2013) over a 20-year period, the NPV of the WWTP is greater than zero, which has a positive figure of $\$ 465,162.48$, the IRR shows a value of $9.14 \%$ which is more than the discount rate, as well as the $\mathrm{B} / \mathrm{C}$ ratio is higher than 2.21 (Table 4). These figures prove that the WWTP project is economically viable for wastewater solutions in order to bring social and economic welfare of the island community.

\subsection{Sensitivity Analysis}

This section examines the effect of the variation in key variables for the WWTP intervention that would affect the CBA outcomes, except for the baseline scenario 
described above. The critical variables of a sensitivity test, which have the greatest impact on the project costs and benefits, include: (i) construction and O\&M costs; (ii) number of households; and (iii) discount rate. Two alternative hypotheses are examined and compared to the baseline case in terms of their impact on the ratio of the WWTP investment.

The first alternative scenario examines the likely impact of the construction cost of the sewage treatment plant. It depicts an increase in the investment cost of about $10 \%$ from the normal circumstance.

Net Present Value $(\mathrm{NPV})=\$ 195,156.68$

Internal Rate of Return (IRR) $=7.83 \%$

Benefit-Cost Ratio $(B / C)=2.01$

The second alternative scenario assumes that the parameters changed include: the discount rate is changed to $9 \%$, a $10 \%$ price increase in construction cost and the number of households is approximately risen by $5 \%$ each year from the year 2016-2035.

Net Present Value $($ NPV) $=\$ 404,525.83$

Internal Rate of Return $($ IRR $)=10.67 \%$

Benefit-Cost Ratio $(B / C)=2.70$

Sensitivity tests show that the CBA outcomes are very sensitive especially to changes in construction cost. The NPV values in both scenarios are positive and greater than zero, which equal to $\$ 195,156.68$ and $\$ 404,525.83$, the $\mathrm{B} / \mathrm{C}$ of scenario 1 is less than the baseline case, but still is more than one. The IRR ratios, which yield $7.83 \%$ and $10.67 \%$, respectively, are still accepted. The results clearly

Table 4 Computation of the cost-benefit analysis over a 20-year period (2014-2035)

\begin{tabular}{ll}
\hline Attribute & Amount or ratio \\
\hline The monetary value of the proposed WWTP & \\
Sample size & 300 households \\
Response rate & $89 \%$ \\
Mean WTP & $\$ 73.36$ per household per year \\
Households in the study area & 4,639 households \\
Estimated total WTP & $\$ 298,774.40$ per year \\
NPV & $\$ 465,162.48$ \\
IRR & $9.14 \%$ \\
B/C ratio & 2.21
\end{tabular}

1. The baseline assumptions based on theory of social cost-benefit analysis and environmental externalities in the financial calculation would be stated as follows: (i) the installation period is 2 years; (ii) all the treatment stages have a lifetime of 20 years, therefore, the benefit are placed 2 years after finishing installation; (iii) the lifespan of the civil construction is 20 years; (iv) discount rate is $7 \%$ per year (365 days in a year) and; (v) prices are constant

2. Calculation discounted amount is based on discount rate of Bank of Thailand, as of May 2013

3. In monetary terms, the intangible costs as well as benefits are very difficult to quantify because they are not captured by the market, such as the impact of effluent qualities from the WWTP, water pollution effects on human health. Due to problems in quantification, thus, such costs and benefits were not included in the calculations 
demonstrate that the proposed WWTP is economically feasible, even if uncertain circumstances occur, since the evaluation criteria are still acceptable under these possible scenarios.

\section{Summary and Conclusions}

This paper aims to elicit households' willingness to pay for a proposed sewage treatment plant to protect ocean beaches. A case study in a rural and coastal tourist area is presented, located at the White Sand Beach of the KCMNP. The joint CVM and CBA applications of wastewater treatment were applied to estimate a valuation of environmental externalities. The successfully completed 300 interviews were analyzed. The Tobit model was used for determination of WTP and the maximum amount of monthly wastewater tariffs that households are willing to pay. Through CVM solicitation, the mean WTP for the provision of wastewater treatment was $\$ 6.03$ per household per month or estimated to be $\$ 73.36$ per household per annum, which is well above a basic annual rate of $\$ 15.67$ charged by the Ko Chang municipalities. The aggregate WTP for all households in the study area was $\$ 298,774.40$ per year.

In addition, the study results provide a systematic process on valuing coastal water resources and conducting the CBA related to the WWTP for coastal water conservation. The net present value is projected to be $\$ 465,162$, the IRR equals $9.14 \%$ which is more than the discount rate and the $\mathrm{B} / \mathrm{C}$ ratio amounts to 2.21 (at a $7 \%$ discount rate over a 20 -year period). The results of CBA in this study show that the WWTP plant is feasible economically. Additionally, the sensitivity tests indicated that the project is contributing to the social and economic welfare, since the B/C, NPV and IRR are also accepted under alternative hypotheses. Consequently, it is a common understanding that this project should be implemented. This suggests that it is worth of undertaking for Thai government to put more investment in the park resource protection.

With regard to the public acceptances toward coastal resource protection, the important policies deserve to be mentioned: (i) on the average, $89 \%$ of households are willing to pay for the construction of a wastewater treatment plant in the region, if such raise in taxes is accompanied by an improved coastal water quality. It is possible for park management to further increase wastewater monthly tariff bills, since the public accepts the additional wastewater charges without jeopardizing household's affordability to pay; (ii) the results obtained from the CVMCBA analysis provide the basic information to suggest the local council authority to operate the over capacity use of coastal resources in a sustainable way that protect coastal waters and support the coastal economy, especially during the peak tourism seasons. Therefore, both Thai central and local governments should take some proactive actions in dealing with environmental protection including ocean resource management, command and control water pollution regulation, and land-use policy for resource use in the future.

Acknowledgments The authors wish to express their appreciation to the DASTA and the KCMNP for their kind assistance and for providing essential information throughout the project, as well as the two anonymous reviewers for their very insightful comments and suggestions on this manuscript in our early inquiry of critics and comments. This study is supported by the National Natural Science Foundation of China Grant No. (70871014) and No. (71271040), and the Institute of High Education Doctor Subject Special Research Fund, Ministry of Education, the People's Republic of China. 


\title{
Appendix: Project Questionnaire
}

Household No.

\section{Household Willingness to Pay for Coastal Water Quality Improvements}

in Ko Chang Marine National Park, Thailand

\author{
Date: \\ Town/village: \\ Time: \\ District \\ Household address:
}

As a result of tourism development, wastewater discharge into the sea is one of the most serious environmental issues in Ko Chang Marine Park, mainly due to sewage drainage from the household and commercial uses. I am conducting this interview concerning wastewater disposal issues in your household for a sustainable coastal water resource management program of Designated Areas for Sustainable Tourism Administration (DASTA) in cooperation with the National Natural Science Foundation of China. The data obtained will be used to elicit willingness to pay for a perceived benefit from the municipal wastewater management. Your response will enable local council authorities to formulate a useful tool for wastewater management strategies in decision-making regarding the sustainable wastewater treatment system in this area.

We will keep all the information you provide is strictly confidential. Ultimately, we do appreciate your cooperation with this project

\section{Note to Enumerators:}

1. Please fill out all information the respondent provides by yourself, write $\mathrm{R}$ if the respondent is unwilling to answer questionnaire, please note the details for non-response.

2. Ask to interview with head of the household, his/ her spouse or a family member aged 20 or above who is responsible for paying the wastewater bill.

Section A: Environmental attitudes and Households' sewage system practices

A1 Household perception of the existing beach condition

Q1 What are the environmental issues related to natural resources facing Ko Chang residents today? (Please apply on a scale from 1 to 3 )
[ ] 1 Coastal water pollution
[ ] 2 Coral reef degradation
[ ] 3 Deforestation
[ ] 4 Air pollution
[ ] 5 Encroachment
[ ] 6 Wastewater treatment
[ ] 7 Solid waste disposal
[ ] 8 Poor drainage / Flooding

[ ] 9 Others (Please specify)

Q2 How much personal experience have you perceived with poor beach conditions that were solid waste -related? (Please circle the number)

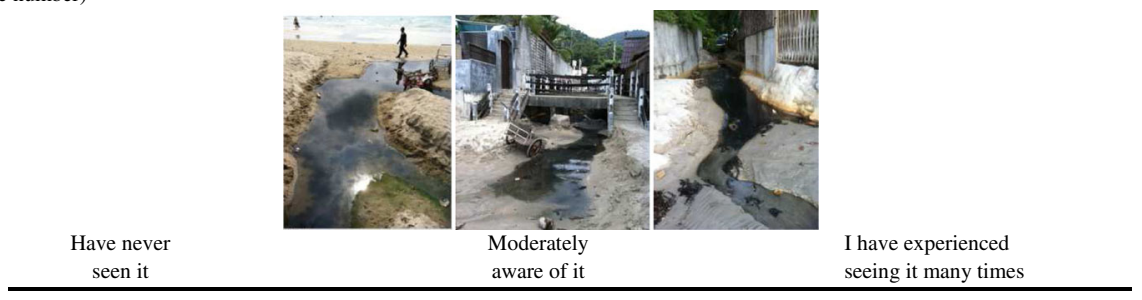


Q3 How would you rate the level of satisfaction with the coastal water quality and reliability at Ko Chang? (Please circle the number)

\begin{tabular}{ccccc} 
Unhappy & Dissatisfied & Neutral & Satisfied & Very satisfied \\
\hline 1 & 2 & 3 & 4 & 5
\end{tabular}

Q4 Has anyone in your household been ill in the past 5 years that associated with exposure to ocean water of poor bacteriological quality?

[ ] 1 Yes, (please specify the name of an illness)

(vomiting, diarrhea, nausea, fever, cramps, ear/nose/throat irritation skin rash, etc.)

[ ] 0 No

Q5 Have you ever noticed any issues of serious water pollution caused by local wastewater for ocean water conservation?
[ ] 1 Yes
[ ] 0 No

\section{A2 Households' sewage system practices}

Q6 What type of wastewater disposal system do your household use currently?

[ ] 1 Public sewerage system

[ ] 2 A private septic tank

[ ] 3 A closed septic tank with an overflow

[ ] 4 All other arrangements (an open ditch, a river, a cesspool, etc.)

[ ] 5 No sewage disposal system

Q7 Does your sewerage and wastewater treatment function work properly?
[ ] 1 Almost always
[ ] 2 Sometimes
[ ] 3 Does not work now

Q8 Where does your wastewater discharge go?
[ ] 1 Municipal sewerage system
[ ] 2 Roadside drain
[ 33 Drainage canal or ditch
[ ] 4 Nearby coastal water body
[ ] 5 Do not know
[ ] 6 Other (Please specify)

Q9 What is the main method of garbage disposal for this household?
[ ] 1 Burning/ Burying
[ ] 2 Fields as fertilizer
[ ] 3 Garbage truck
[ ] 4 Dumping in sea/river/pond/gully
[ ] 5 Dumping at municipal site
[ ] 6 Other (Please specify)

Q10 How would you rate the existing wastewater treatment solution of the municipalities?

\begin{tabular}{ccccc} 
Unhappy & Dissatisfied & Neutral & Satisfied & Pleased \\
\hline 1 & 2 & 3 & 4 & 5
\end{tabular}

Q11 Would you prefer to have an improved sewage disposal system?
[ ] 1 Yes
[ ] 0 No

Q12 Which of the following improved wastewater disposal systems do you prefer?
[ ] 1 Central sewerage system
[ ] 2 Septic tank and soak-away
[ ] 3 Open drainage canals
[ ] 4 Other (specify)

Q13 How much are you charged wastewater tariffs per year for the sewer treatment services? US\$

Q14 What do you think about the current wastewater tariffs compared with other utility payments such as the water supply bill?
[ ] 1 Too low [ ] 2 Normal
[ ] 3 Too high
[ ] 4 Do not know 
Section B: Willingness to pay for Coastal Water Quality Improvements

Ko Chang Marine National Park is one of the mass tourism destinations particularly popular with the white sandy beaches and coral reef systems. Since 2005, many destinations and regions in Ko Chang concerning with wastewater are becoming a pressing challenge as the amount of waste increases and the cost of dealing with this waste in a sustainable manner rise at an ever increasing rate. For example, White Sand beach is the most popular recreational area, and there is potential to further develop the bathing beach and tourism activities. Recently, White Sand beach is highly polluted with biological organisms, largely from household and tourism wastes. Overflow from household sewage drains into surface water, particularly small confined lakes and water bodies, the contained nutrients may produce high bacterial levels in the sea. Such a bacterial contamination in the sewagepolluted seawater causes serious threats to human risks and aquatic life (please see picture A).

The Ko Chang municipalities and DASTA realized that the treatment of wastewater was insufficient and a serious problem. Establishing a centralized sewerage system should be a high priority throughout White Sand beach area, which is still largely lacking proper treatment. A pilot sewerage treatment is designed to clean pollutant wastewater through a network for wastewater collection, treatment and reuse or disposal of effluent and sludge.

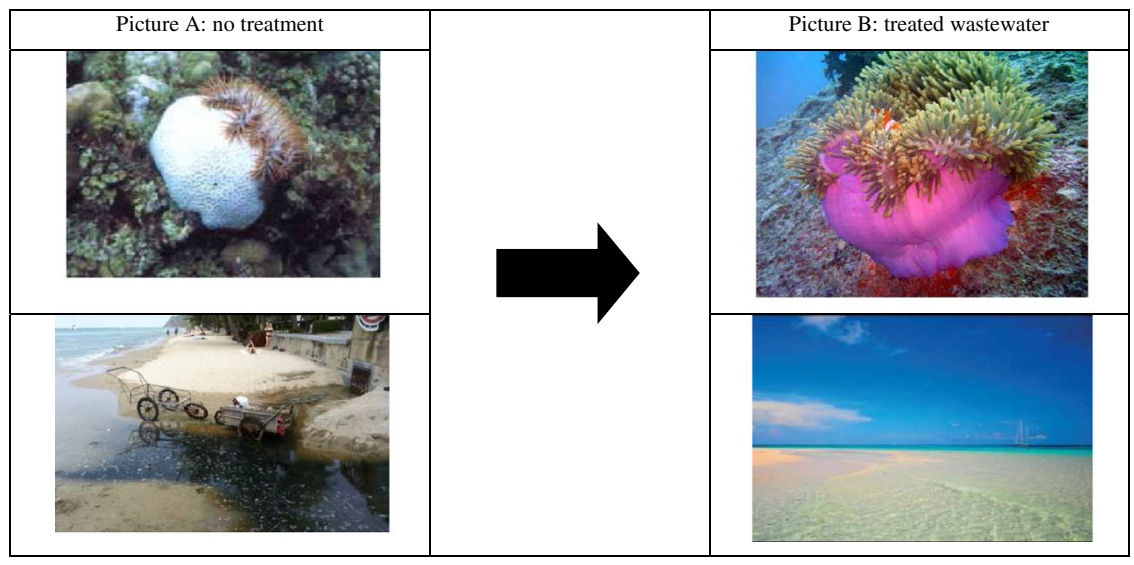

After establishing treatment unit, the centralized system receives and treats wastewater from the surrounding communities and the tourism industry along the entire White Sand beach, it is capable of providing high-level treatment for an average daily flow of 1.35 million litres and servicing approximately 500,000 people per year, the water from the treatment plant could then be discharged safely into the ocean water, so that the treated water will have minimal impact on the environment when it is returned. As a result, the benefits from the sewage plant could be served local population in order to reduce health risks when directly contact water and also improve recreational waters near this facility (please see picture B).

Q15. The construction cost of the treatment plant will be covered by the Ko Chang municipalities and will be extrapolated to the residents by charging monthly tariff bill. After the WWTP is installed by 2016, it would cost to your household $\$$ X per month. Would your household be willing to pay monthly tax to support this project?

[ ] 1 Yes

[ ] 0 No (please follow up Q16)

If YES, please indicate your maximum willingness to pay by checking the appropriate box for the amount of the monthly tariff bill to be collected-or fill in another monthly amount: $\$ 0, \$ 1, \$ 3, \$ 5, \$ 7, \$ 10$, $\$ 15$, or other 
Q16 If NO PAYMENT, Could you please describe the reasons why you are not willing to pay?

[ ] 1 I can not afford to pay more taxes

[ ] 2 It's the municipal government's responsibility

[ ] 3 I needed more information before decide to pay

[ ] 4 I mistrust this payment will lead the improvement as claimed

[ ] 5 I feel satisfied with the existing beach condition

\section{Section C: Socioeconomic Profile}

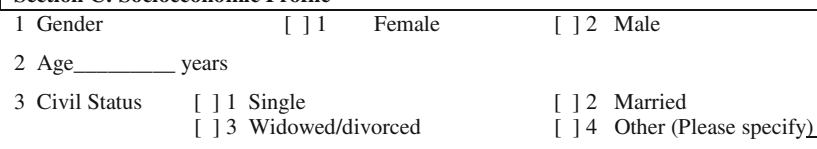
4 Are you head of the household?
[ ] 1 yes
[ ] 0 No

5 Household size: (Number of family members)

6 How long have you been living in this area?
[ ] 1 Less than 1 year
[ ] 21 to 5 years
[ ] 3 6-10 years
[ ] 4 Over 10 years

7 What is the ownership status of the house in which you live?
[ ]1 Own house
[ ] 2 Rented
[ ] 3 State house
[ ] 4 Company guesthouse
[ ] 5 Company guesthouse
[ ] 6 Other, please specify

8 Highest level of education completed
[ ] 1 No Schooling
[ ] 3 High school/ Vocational diploma

[ ] 2 Primary Education /Secondary Education

[ ] 4 College degree

[ ] 5 Master degree or higher

[ ] 6 Other, please specify

9 What is your profession

10 What is your employment type?
[ ] 1 Permanent
[ ] 2 Seasonal
[ ] 3 Contract
[ ] 4 Other (Please specify)

11 How many family members contribute to the household income?

11-1 Please indicate your family members' profession

12 What is your average monthly household income (before tax)? (US\$ dollar)

Thank you for your time and cooperation 


\section{References}

Ahmed SU, Gotoh K (2006) Cost-benefit analysis of environmental goods by applying the contingent valuation method: Some Japanese case studies. Springer, Japan

Ajzen I, Brown TC, Carvajal F (2004) Explaining the discrepancy between intentions and actions: the case of hypothetical bias in contingent valuation. Pers Soc Psychol B 30(9):1108-1121. doi:10.1177/ 0146167204264079

Amemiya T (1973) Regression analysis when the dependent variable is truncated normal. Econometrica 41(6): 997-1016. doi:10.2307/1914031

Báez A, Herrero LC (2012) Using contingent valuation and cost benefit analysis to design a policy for restoring cultural heritage. J Cult Herit 13(3):235-245

Bank of Thailand (2013) Discount and foreign exchange rates 2013. http:/www.bot.or.th/Thai/Statistics/ FinancialMarkets/ExchangeRate/_layouts/Application/ExchangeRate/ExchangeRate.aspx. Accessed 30 May 2013

Bateman I, Langford IH, Willis KG, Turner K, Garrod GG (1993) The impacts of changing willingness to pay, question format in contingent valuation studies: An analysis of open-ended, iterative bidding and dichotomous choice formats. Global Environmental Change Working Papers 93-05, Centre for Social and Economic Research on the Global Environment, University of East Anglia, Norwich, UK

Bateman IJ, Cole MA, Georgiou S, Hadley DJ (2006) Comparing contingent valuation and contingent ranking: a case study considering the benefits of urban river quality improvements. J Environ Manag 79(3):221-231. doi:10.1016/j.jenvman.2005.06.010

Bengochea A, Fuertes AM, del Saz S (2005) A comparison of empirical models used to infer the willingness to pay in contingent valuation. Empir Econ 30(1):235-244. doi:10.1007/s00181-005-0236-x

Bergstrom JC, Boyle K, Poe G (2000) The economic valuation of water quality. Edward Elgar Publishers, Cheltenham

Berrens RP, Bohara AK, Kerkvliet J (1997) A randomized response approach to dichotomous choice contingent valuation. Am J Agric Econ 79(1):252-266. doi:10.2307/1243959

Birol E, Karousakis K, Koundouri P (2006) Using economic valuation techniques to inform water resources management: a survey and critical appraisal of available techniques and an application. Sci Total Environ 365(1-3):105-122. doi:10.1016/j.scitotenv.2006.02.032

Bockstael NE, Mcconnell KE, Strand LE (1989) Measuring the benefits of improvements in water quality: the Chesapeake Bay. Mar Resour Econ 6:1-18

Bord RJ, O'Connor RE (1997) The gender gap in environmental attitudes: the case of perceived vulnerability to risk. Soc Sci 78(4):830-840

Brouwer R (2000) Environmental value transfer: state of the art and future prospects. Ecol Econ 32(1):137-152. doi:10.4337/9781781008102.00015

Brown K, Taylor L (2000) Do as you say, say as you do: evidence on gender differences in actual and stated contributions to public goods. J Econ Behav Organ 43(1):127-139. doi:10.1016/S0167-2681(00)00113-X

Carson RT (2012) Contingent valuation: a practical alternative when prices aren't available. J Econ Perspect 26(4):27-42

Carson RT, Flores NE, Meade NF (2001) Contingent valuation controversies and evidence. Environ Resour Econ 19:173-210

Chen WY, Jim CY (2008) Cost-benefit analysis of the leisure value of urban greening in the new Chinese city of Zhuhai. Cities 25(5):298-309. doi:10.1016/j.cities.2008.06.002

Cho SH, Newman DH, Bowker JM (2005) Measuring rural homeowners' willingness to pay for land conservation easements. For Policy Econ 7:757-770. doi:10.1016/j.forpol.2005.03.007

Collins JP, Vossler C (2009) Incentive compatibility tests of choice experiment value elicitation questions. J Environ Econ Manag 58(2):226-235. doi:10.1016/j.jeem.2009.04.004

Crites R, Tchobanoglous G (1998) Small and decentralized wastewater management systems. McGraw-Hill, Boston

Del Saz S, Hernández F, Sala R (2009) The social benefits of restoring water quality in the context of the Water Framework Directive: a comparison of willingness to pay and willingness to accept. Sci Total Environ 407(16):4574-4583. doi:10.1016/j.scitotenv.2009.05.010

Department of Mineral Resources Thailand (2013) Geology for coastal management of Thailand. http://www. dmr.go.th/ewtadmin/ewt/dmr_web/main.php?filename=geo_coastal_EN. Accessed 23 Sep 2013

Department of Tourism (2013) Number of visitors to Ko Chang Marine National Park 2003-2012. http://www. tourism.go.th/tourism/index_weloveking.php. Accessed 30 Sep 2013

Designated Areas for Sustainable Tourism Administration (DASTA) (2013) Annual Report 2013, Bangkok, Thailand

Forster BA (1989) Valuing outdoor recreational activity: a methodological survey. J Leis Res 21:181-201

Godfrey S, Labhasetwar P, Wate S (2009) Greywater reuse in residential school in Madhya Pradesh, India, a case study of cost-benefit analysis. Resour Conserv Recycl 53(5):287-293. doi:10.1016/j.resconrec.2009.01.001 
Green D, Jacowitz KE, Kahneman D, MacFadden D (1998) Referendum contingent valuation, anchoring and wiliingness to pay for public goods. Resour Energy 20(2):85-116. doi:10.1016/S0928-7655(97)00031-6

Greene WH (2000) Econometric analysis, 4th edn. Prentice Hall, New Jersey

Günay K (1989) The relationship between coastal tourism, sea pollution and public health: a case study from Turkey. Environmentalist 9(4):245-251. doi:10.1007/BF02241824

Hanley N, Colombo S, Kristrom B, Watson F (2009) Accounting for negative, zero and positive willingness to pay for landscape change in a national park. J Agric Econ 60(1):1-16. doi:10.1111/j.1477-9552.2008.00180

Hausman J (2012) Contingent valuation: from dubious to hopeless. J Econ Perspect 26(4):43-56. doi:10.1257/jep.26.4.43

Howarth BR, Farber S (2002) Accounting for the value of ecosystem services. Ecol Econ 41(3):421-429. doi:10. 1016/S0921-8009(02)00091-5

Huhtala A (2004) What price recreation in Finland? A contingent valuation study of non-market benefits of public outdoor recreation areas. J Leis Res 36(1):23-44

Johnston J, Dindaro J (1997) Econometric methods, 4th edn. McGraw Hill, New York

McDonald JF, Moffitt RA (1980) The use of Tobit analysis. Rev Econ Stat 62:318-321

Mitchell RC, Carson RT (1989) Using surveys to value public goods: The contingent valuation method. Resources for the Future, Washington, DC, p 463

Mitchell RC, Carson RT (1995) Current issues in the design, administration, and analysis of contingent valuation surveys. In: Johansson PO, Kriström B, Mäler KG (eds) Current issues in environmental economics. Manchester University Press, Manchester, pp 10-34

Molinos M, Hernández F, Sala R (2010) Economic feasibility study for wastewater treatment: a cost-benefit analysis. Sci Total Environ 408(20):4396-4402. doi:10.1016/j.scitotenv.2010.07.014

Mu Ko Chang National Park (2013) General Information. http://www.dnp.go.th/parkreserve/asp/style1/default. asp?npid=211\&lg=2. Accessed 15 Sep 2013

National Statistical Office, Thailand (2013) Ko Chang Marine National Park Population 2011 http://web.nso.go. th. Accessed 12 Sep 2013

Nunes Paulo ALD (2002) The contingent valuation of natural parks: Assessing the Warmglow propensity factor. Edward Elgar, Northampton, p 288pp

Pavlikakis GE, Tsihrintzis VA (2003) A quantitative model for accounting human opinion, preferences and perceptions in ecosystem management. J Environ Manag 68(2):193-205. doi:10.1016/S0301-4797(03)00067-7

Pavlikakis GE, Tsihrintzis VA (2006) Perceptions and preferences of the local population in Eastern Macedonia and Thrace National Park in Greece. Landsc Urban Plan 77(1-2):1-16. doi:10.1016/j.landurbplan.2004.12. 008

Penning RE, Johnson C, Tunstall S et al (2005) The benefits of flood and coastal risk management: A manual of assessment techniques. Middlesex University Press, London

Poe GL, Vossler CA (2011) Consequentiality and contingent values: An emerging paradigm. In: Bennett J (ed) The international handbook on non-market environmental valuation. Edward Elgar Publishing Limited, Cheltenham

Prest AR, Turvey R (1965) Cost-benefit analysis: a survey. Econ J 75:683-735. doi:10.2307/2229670

Price C (2000) Valuation of unpriced products: contingent valuation, cost-benefit analysis and participatory democracy. Land Use Policy 17:187-196. doi:10.1016/S0264-8377(00)00020-X

Prihandrijanti M, Malisie A, Otterpohl R (2008) Cost-benefit analysis for centralized and decentralized wastewater treatment system (Case study in Surabaya-Indonesia). Efficient management of wastewater, its treatment and reuse in water-scarce countries. Springer, Verlag Berlin Heidelberg, Berlin, pp 259-268

Roebeling PC, Coelho CD, Reis EM (2011) Coastal erosion and coastal defense interventions: a cost-benefit analysis. J Coast Res Spec Issue 64:1415-1419

Seguí L, Alfranca O, García J (2009) Techno-economical evaluation of water reuse for wetland restoration: a case study in a natural park on Catalonia, Northeastern Spain. Desalination 246:179-189. doi:10.1016/j.desal. 2008.03.051

Stern P, Dietz T, Kalof L (1993) Value orientations, gender, and environmental concern. Environ Behav 25(3): 322-348. doi: $10.1177 / 0013916593255002$

Stewart R, Possingham H (2005) Efficiency, costs and trade-offs in marine reserve system design. Environ Model Assess 10:203-213. doi:10.1007/s10666-005-9001-y

Tokich SH, Kliot N (2008) Inter-municipal cooperation for wastewater treatment: case studies from Israel. J Environ Manag 86(3):554. doi:10.1016/j.jenvman.2006.12.015

Tourism Authority of Thailand (2013) Interactive map: Mu Ko Chang Marine National Park http://www. tourismthailand.org/travel-and-transport/interactive-map. Accessed 15 Dec 2013

United Nations Environment Programme (2007) UNEP/GEF project on reversing environmental degradation trends in the South China Sea and gulf of Thailand, coral reef demonstration site, Mu Koh Chang, Thailand. http://www.unepscs.org/components/com_remository_files/downloads/MRT-4-D2-Koh-Chang.pdf. Accessed 19 Aug 2013 
Verlicchi P, Aukidy M, Galletti A et al (2012) A project of reuse of reclaimed wastewater in the Po valley, Italy: polishing sequence and cost benefit analysis. J Hydrol 432-433:127-136. doi:10. 1016/j.jhydrol.2012.02.024

Wendimu S, Bekele W (2011) Determinants of individual willingness to pay for quality water supply: the case of Wonji Shoa Sugar Estate, Ethiopia. J Ecol Nat Environ 3(15):474-480. doi:10.5897/ JENE11.089

Wilderer PA, Schreff D (2000) Decentralized and centralized wastewater management: a challenge for technology developers. Water Sci Technol 41(1):1-8

Wooldridge J (2002) Econometric analysis of cross section and panel data. MIT Press, London

Yoo SH, Kim TY, Lee JK (2001) Modeling zero response data from willingness to pay surveys A semi-parametric estimation. Econ Lett 71:191-196. doi:10.1016/S01651765(01)00363-9

Zerbe RO, Dively DD (1994) Benefit-cost analysis in theory and practice. Harper Collins College Publishers, New York 